\title{
The impact of financial globalization and financialization on the economy in the current crisis through banking corporate governance
}

\author{
Juan Antonio Azkunaga', Leire San-Jose ${ }^{1,2}$, Sara Urionabarrenetxea'
}

\begin{abstract}
This work analyzes the role of governance of financial entities in the current crisis. Neoliberal economic policies, deregulation and liberalization have characterized financial globalization, giving rise to the financialization of the economy. This paper, using the analysis-synthesis method, shows that the corporate governance of entities has adapted to the new social environment under the influence of the interests of the investors. The results of this paper suggest the need to monitor the over-emphasis on the maximization of short-term shareholder value without relativizing the risk taken to achieve it, as such, the emphasis on short-term shareholder value is considered a crucial contributing factor to the present crisis.
\end{abstract}

KEY WORDS: $\quad$ corporate governance; banks, globalization; financial crisis; institutional investors.

JEL Classification: F30, G01, G21, G34.

${ }^{1}$ University Of The Basque Country, Spain, ${ }^{2}$ University of Huddersfield, United Kingdom

\section{Introduction}

The role played by neoliberalism (Harvey, 2005), the dominant economic thinking of the last quarter of the $20^{\text {th }}$ century, is striking. It was this theory that served as the foundation of the economic policies adopted since the 1980s, and it was grounded in assumptions about the rationality of agents and the efficiency of markets, all of which can be questioned. Following this theory, liberalization and deregulation were strongly promoted and drove the financial entities in the direction of the free market where financial agents could act with greater freedom. The development of financial ㅁ. globalization was thereby fostered; however, the finan-

Correspondence concerning this article should be addressed to: Leire San-Jose, University Of The Basque Country, Avda. Lehendakari Agirre 83, Bilbao 48014, Spain, e-mail: leire.sanjose@ehu.es cial entities found it easier to behave with less control and to take inappropriate actions.

The gestation and outbreak of the contemporary crisis is a problem generally associated with neoliberalism and, thus, with financial globalization, financialization and corporate governance. Therefore, the roles and implications of these three factors on the current crisis are explored. Moreover, the influence of the financial sector and its role in the financial crisis is of significant. While the understanding of what constitutes an effective governance structure for a financial firm is complicated by several factors, it is necessary to understand the structure when examining the factors that contributed to the crisis.

There is a vast amount of literature regarding governance during the last several years (Adams, 2012; Alvarez Peralta \& Medialdea, 2010; Field \& Pérez, 2009; 
Kowalewski, 2012; Laeven \& Levine 2009; Purnanandan, 2010; Roldán, 2008; Ruiz \& Urra, 2009). Studies that address corporate governance have emphasized those features of corporate governance that contributed to the development of the crisis, but the studies have not examined the reasons that made it possible (Greenspan, 2010; Klicksberg, 2010; Organization for Economic Cooperation and Development [OECD], 2008 ; 2009). To date, there has been no in-depth analysis of corporate banking governance, even though there is wide interest in corporate governance not only from an academic perspective but also from the practitioner's perspective with respect to financial entities. Ideally, the academic governance literature would analyze the entire banking sector, but perhaps because of the particular nature of the financial sector, most academic papers exclude financial firms from their data and focus on the governance of non-financial firms (San-Jose, et al., 2013). Consistent with this premise, Adams (2012: 34) establishes that in banking corporate governance, "ex post, it is easy to argue that governance problems occurred, but ex ante it is not clear that boards of financial firms were doing anything much different from boards in other firms". However, it is necessary to improve the management policy of corporate governance in the banking sector. Therefore, to obtain a picture of the state of the moral hazard in the financial sector, through banking corporate governance, it is useful to directly examine the main characteristics and, therefore, the causes of the current crisis.

Specifically, the main changes that have occurred during the last three decades were marked by financial globalization. What characterized this period were neoliberal economic policies, deregulation and financial liberalization. From a critical perspective of the neoliberal nature of the policies introduced in the management of the globalization process, a description is given of the factors that caused the corporate governance of financial entities to concentrate unduly on short-term maximization of shareholder value, which was a crucial determinant in the present crisis. We will take a particularly close look at the relation between these changes and the evolution of governance and how the crisis was fueled. The analysis of the secondary data is made within the financial literature, and a study is conducted with financial experts during workshops to determine the causes behind the crisis to contribute to the governance literature regarding banking. Specifically, workshops were held at the University of the Basque Country (Bilbao-Spain) with ECRI Ethics in Finance \& Governance. Stakeholders Responsibility Research Group: the first with Professor Chris Cowton, Dean of Huddersfield Business School in the United Kingdom in March 2011, the second with Professor Antonio Argandoña from IESE Business School in Spain in July 2012, and the third with Professor Miguel Alzola from Fordham University of New York in the United States in October 2012.

This work aims to analyze the way in which the financial globalization and financialization of the economy through the governance of banking institutions contributed to the development and outbreak of the crisis, and it raises the possibility that it could be a basic problem of moral hazard. Our study, in addition to synthesizing investigations that have been conducted in this field, contributes an analysis of the factors that led to the evolution of the corporate governance of institutions and thereby bolstered the gestation and outbreak of the crisis. Moreover, the results suggest that the changes and reforms that should be implemented must cover structural features in the way financial entities are governed, so that, for instance, the interests of other groups that participate in financial entities, as well as shareholder interests, would be taken into consideration.

The remainder of this paper is organized as follows. First, the theory and previous studies about financial globalization, financialization and corporate governance are explained. Section 3 describes the corporate governance in banking during the current financial crisis based on short-term management, institutional investor positions and actuations and on incentives role in aligning the interests of managers with those of bank owners. Following the results of the main elements of current financial crisis based on a banking analysis, the moral hazard and originate-to-distribute model for financial entities are suggested. Finally, Section 5 offers main conclusions, limitations and future lines of research.

\section{Review of literature: financial globalization, financialization and corporate governance}

The financial globalization process, which intensified in the 1980s, has contributed to the financialization of the economy, which created the necessary condi- 


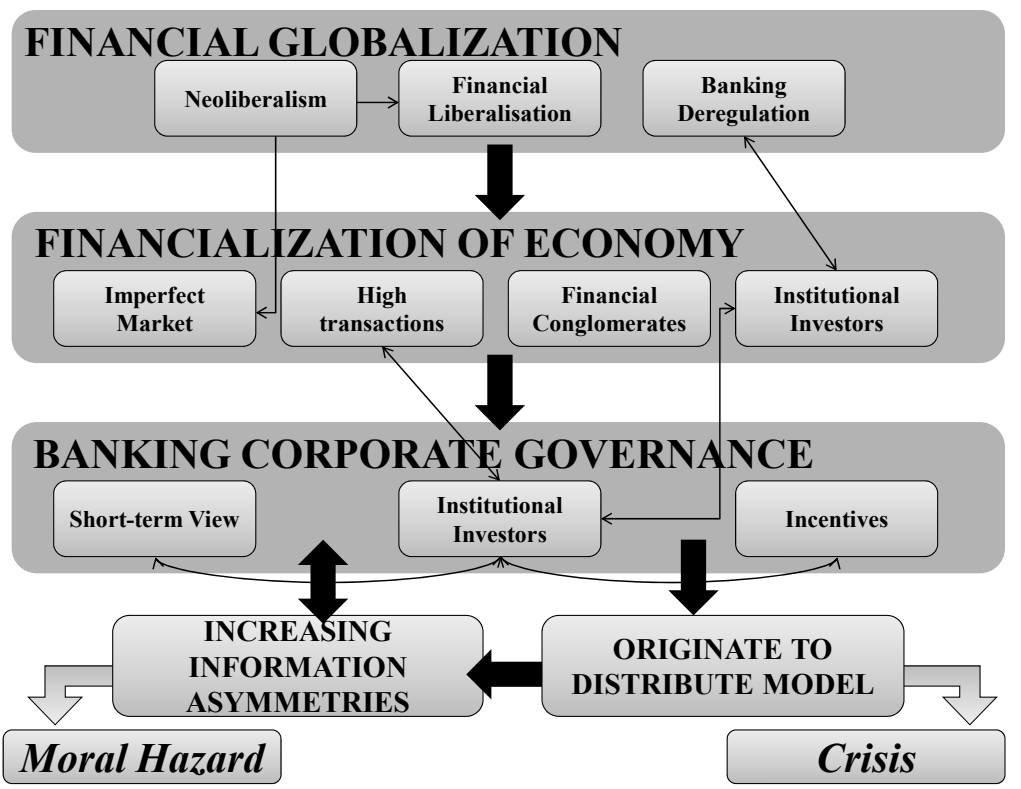

Figure 1. Evolution of corporate bank governance and its relation with the current crisis.

tions for an unprecedented development of institutional investors (Alvarez Peralta \& Medialdea, 2010). Moreover, the entry of institutional investors into the company share structure has constituted a mechanism through which the evolution of the corporate governance of financial entities has been promoted (Alvarez Peralta \& Medialdea, 2010). The most relevant issues that impacted, either directly or indirectly, banking during the crisis and are related to corporate governance of financial entities include financial globalization, financialization of the economy and corporate governance in banking (See Figure 1):

\section{Financial Globalization}

Financial globalization involves increasingly greater integration of different national financial markets within international financial markets, resulting in a growth in financial relations and transnational financial flows at a global level (Urionabarrenetxea, Bañales \& Garcia, 2009). Furthermore, it represents a substan- tial change in the environment where financial entities develop their business and, consequently, it has important implications for the corporate governance of financial entities, which must evolve to adapt to the new situation (Adams, 2012). As this phenomenon is broad and complex, it is wise to break it down into its different features. The main foundation upon which globalization has developed is neoliberalism, financial liberalization and deregulation (Urionabarrenetxea et al., 2009; Wilczyński, 2011).

The free market and neoliberal economic policies According to Harvey (2005), "neoliberalism is in the first instance a theory of political economic practices that proposes that human well-being can best be advanced by liberating individual entrepreneurial freedoms and skills within an institutional framework characterized by strong private property rights, free markets and free trade" (p. 2). The neoliberal theory is rooted in authors such as Friedman (1962), Lucas 
(1972), and Fama (1970). This new paradigm gave rise to important transformations in different spheres of the financial sector (Recio, 2009):

- The creation of financial assets and capital movements between different countries was liberalized. In addition, there was a progressive substitution of public regulation by the self-regulation of the markets. These factors have encouraged the development and growing complexity of the financial system.

- Within the business area, the vision of business became more short-term and the approach to incentivizing managers changed, depending more on short-term company results and on the evolution of share prices. Therefore, companies acted consistent with the image they projected in the market, seeking short-term stock market revaluations rather than investments that would bear fruit in the longer term.

This theory generates problems and crises (Stiglitz, 2002) and particularly has played a role in the current crisis (Akerlof \& Shiller, 2009; Greenspan, 2010; Jakóbik, 2011; Recio, 2009; Stiglitz, 2010). Moreover, Stiglitz $(2002 ; 2010)$ and Recio (2009) show specifically that the effect of destabilization produced by the application of neoliberal policies discredits the theory because it is grounded in theoretical concepts that do not match reality. Some of the principal assumptions of neoliberal financial capitalism, which constitute the foundations of the present economic theory, have been questioned, and the most important arguments are that there is a lack of necessary information regarding decisions made by agents (Stiglitz, 2010) leading to an inefficient market (De la Dehesa, 2009; Summers, 1985) and the incomplete rationalization of expectations (Akerlof \& Shiller, 2009). Consequently, as the underlying assumptions are erroneous, so are also the models based on the assumptions, which were initially employed to explain and predict the evolution of the economy. Consequently, the economic policies based on the predictions will be equally flawed (Stiglitz, 2010).

\section{Financial liberalization}

For the development of financial globalization, financial markets must be open to foreign markets and movements of capital must be allowed. This must then be followed by the elimination of restrictions on the transit of goods and capital across frontiers (Estévez, 2009). This process was set in motion in the 1980s and is ongoing. Liberalization increases competition by allowing new agents to participate in the market who were previously not able to do so (Levine, 2001).

Economic theory attributes several benefits to liberalization for those economies that implement it because liberalization improves the functioning and efficiency of the financial system, which is fundamental for stimulating economic growth:

- Liberalization produces a growth in competition and in the scope and depth of the markets, thereby increasing efficiency and causing a reduction in interest rates, both of which benefit economic growth (Arestis, Troncoso and Cavalcante, 2009).

- Agents can profit from a greater diversification of risk (Rodrik, 2001) and from greater possibilities of access to financing (Edison, Levine, Ricci, \& Sløk, 2002).

- Financial entities improve their solvency and operations are more transparent (World Economic Outlook, 2006).

- Liberalization favors the economic growth of developing countries because it attracts more direct investment, which tends to be accompanied by technology transfers (Keller, 2002).

Nevertheless, liberalization also involves negative consequences, particularly in terms of increasing instability, as Díaz-Alejandro (1985) made clear after analyzing the liberalizations of countries in the South American Cone and as Stiglitz did in alluding to the Thai crisis of 1997 (Stiglitz, 2002).

Bordo et al. (2001) found that in the globalization period of reference there was an increase in financial instability. Attempts have been made to relate this greater instability to liberalization, but there have been no conclusive results. While there are studies whose outcomes reach such an assertion (Aizenman, 2002; Kaminsky \& Reinhart, 1999; Kaminsky, Linzondo \& Reinhart, 1998) other studies conclude that this causeeffect relation between instability and financial liberalization does not exist (Richards, 1996; De Santis \& Imrohoroglu, 1997). In general, however, it is accepted that financial liberalization is considered to be one of the underlying factors behind the growth of instability and the financial crisis (Calvo \& Mendoza, 2000). 


\section{Banking deregulation}

Given that financial regulation is the set of laws and rules that denote the functioning, risk control and other features of financial activity, it is necessary to study bank behavior and its effect on financial globalization. Banking authorities have the power to set these rules and make it obligatory that financial institutions comply with them to ensure that the entities behave prudently because they safeguard the capital of depositors (Zamil, 2010).

The regulations aimed to produce financial stability and guarantee that credit would be efficiently designated to provide investment support (Arestis et al., 2009; Wilczyński, 2011), which is one of the fundamental services that banks must offer the economy (De la Dehesa, 2009). In the 1970s, with the integration of the neoliberal paradigm, a deregulating process began that was intended to move toward a free market and promote greater economic growth, thus giving incentives to private savings and to competition (Recio, 2009). It is a process that involves the repeal of regulations on company activity and on the content of contracts (Estévez, 2009).

Its supporters advanced arguments based on the search for greater economic efficiency through market freedom (Recalde, 2009) or on the reduction of inefficiencies that arise when the public and the private sectors compete for capital, thus producing price distortions (Summers, 1986; Soto, 2010). The supporters also considered that regulations should lead to solutions provided by technicians and experts, who were better equipped to address the situation (Recalde, 2009).

Where banking business was concerned, the most important legislative changes occurred in the 1980s, with the deregulation of the granting of loans. In the United States, the "Depositary Institution Deregulation and Monetary Control Act" of 1980 was enacted, which liberalized the granting of credits and the interests and allowed commercial banks to reduce their reserves. During the 1990s, the deregulatory tendency increased and the main regulatory changes were implemented. In 1994, there was a deregulation of banking activity among different states in the United Statesin the form of the "Riegle-Neal Act". In 1999, the "Gramm-Leach-Billey Act" repealed the "Glass-Steagal Act" of 1933, suppressing the distinction between business that could be conducted by commercial banks and investment banks and fostering the creation of enterprises that offered banking, investment and insurance services (Estévez, 2009).

\section{Financialization of the Economy}

As a consequence of globalization, which has been influenced by neoliberalism and driven by liberalization and deregulation, the economic environment in which banking institutions conduct their business experienced a marked change (Levine, 2001) known as the financialization of the economy, an event relevant for understanding the evolution of banking governance.

During the three decades that preceded the present crisis, the financial sector increasingly carried more weight. In the United States, for instance, the percentage of profits in the financial sector compared to the total business profits in 2007 was $27 \%$, whereas in 1980, it scarcely reached 15\% (Financial Crisis Inquiry Commission, 2011). Transactions of a financial nature also witnessed significant growth. For example, between 1990 and 2005, the volume of transactions in the equity markets multiplied by 9 ; in derivatives, the volume multiplied by 4 ; and in currencies, the volume multiplied by 3.5 (Alvarez Peralta \& Medialdea, 2009).

After analyzing several definitions of the term financialization and synthesizing those definitions, we define financialization as the process whereby there is an increase in the importance of the financial sector in the economy (Blasiak, 2010). Financial markets, financial institutions and financial motivations take on increasing relevance in domestic economies as well as in the international economy (Alvarez Peralta \& Medialdea, 2010).

The globalization process and subsequent financialization have produced a series of transformations in the international financial markets (Alvarez Peralta \& Medialdea, 2010; Falkowski, 2011). Among these transformations, we highlight four that have contributed significantly to the evolution of today's crisis.

1 Imperfections in the financial markets have continued and, in essence, they are associated with the information asymmetries between creditors and debtors and are the basis for the financial problems in the economy (Mishkin, 1999). Specifically, the financial contagion problem and uncertainties in financial-decisions and financial instability could be the results of the increments in these asymmetries (Álvarez Peralta \& Medialdea, 2010). 
2 Because the financial markets have become globalized, agents act in many different markets and have the opportunity to move capital quickly and cheaply from one place to another.

3 With the disappearance of the distinction between the types of business that commercial banking and investment banking can develop and as a result of the "Gramm-Leach-Billey Act" of 1999, conglomerates have been formed integrating different financial functions within a single institution (commercial banking, investment banking, insurance, asset administration, investment funds, etc.)

4 The relevance and importance of institutional investors have increased (Alvarez Peralta \& Medialdea, 2010; Becht, Bolton, \& Röell, 2002).

In the specific case of the banking sector, financialization has had decisive consequences on the way the entities function internally, that is, changes have occurred in the institutions' corporate governance and in the banking management models (Field \& Pérez, 2009; Jackowicz, Kowalewski \& Kozłowski, 2011; Purnanandan, 2010; Roldán, 2008; Ruiz \& Urra, 2009).

\section{Banking Corporate Governance}

The corporate governance of financial entities is one of the causes of the current crisis (OECD, 2008; 2009). Thus far, this question has been tackled descriptively, with an emphasis on the different areas of governance that have encouraged the crisis.

Corporate governance has principally captured the interest of academic literature over the last two decades due, above all, to the business insolvencies and scandals that have been occurring (La Porta, Lopez-de-Silanes, Shleifer, \& Vishny, 2000; Shleifer \& Vishny, 1997). Numerous studies have been published in this regard, along with a series of codes, laws and principles that have sought to improve the standards that govern corporate governance to address the weaknesses that have been identified (Adams, 2012). Among these standards are the "Cadbury Report" (The Committee on the Financial Aspects of Corporate Governance, 1992), the Sarbanes-Oxley Act, which was passed in the United States on 30 July 2002, and the principles of the OECD for corporate governance (Organization for Economic Cooperation and Development [OECD], 2004). Despite the contributions made over the last decade to improve it, the problems related with corporate governance have been singled out as crucial for explaining what has happened during this crisis (European Commission, 2010; OECD, 2008).

In the "Cadbury Report", corporate governance is defined as a system through which companies are managed and controlled (The Committee on the Financial Aspects of Corporate Governance, 1992). As such, it involves a series of relations between the different interested parties in the company and those that manage it (OECD, 2004; European Commission, 2010), and it encompasses contracts, processes and mechanisms for decision making that attempt to ensure that the management applied in the company by the managers is in alignment with the objectives of the shareholders and other interested parties (Spong \& Sullivan, 2012).

More than one perspective can be adopted for deciding which interested parties should be considered in company management (Ludescher, Mashud \& Prusia, 2012):

- There is a view based on shareholder orientation (Friedman, 1962) that to establish the objectives of corporate governance, only shareholder interests should be considered.

Another orientation, stakeholder orientation, adopts a broader perspective and recognizes that there are various interested collectives, that is, stakeholders, such as staff, customers, suppliers, the community, regulatory bodies, small investors, etc. (Freeman, 1984), should be given the chance to defend their interests by participating in the governing bodies of the entities (San-Jose \& Retolaza, 2012) and that without these stakeholders the company cannot be successful.

The first of these two perspectives is the common orientation applied in companies and, in the last few years, also applied in financial entities. There are studies, however, that suggest that, in general, only twothirds of the management of the company is based on shareholder-orientation (Omran, Atrill \& Pointon, 2003). Thus, the real management orientation is difficult to describe from a robust empirical perspective.

Another characteristic of current corporate governance is that one of its main objectives is to address the inefficiencies that stem from the separation be- 
tween ownership and control of the company (Jensen \& Meckling, 1976). Accordingly, the purpose of governance should be the alignment of managerial actions with the company's objective, that is, to maximize shareholder wealth (Sternberg, 1998).

Based on the shareholder-orientation approach toward company corporate governance, companies become sensitive toward the rights and desires of the shareholders (The Committee on the Financial Aspects of Corporate Governance, 1992), and therefore, corporate governance attempts to create mechanisms that ensure management (the agent) is governed by contracts, applies certain processes and makes decisions that benefit the interests of the company owners. According to the postulates of agency theory (Jensen \& Meckling, 1976), the question is to resolve the conflicts of interests that arise between shareholders (principals) and management (agent). A prominent role in the gestation of today's crisis is attributed to this view of governance aimed at satisfying shareholder rights (Alvarez Peralta \& Medialdea, 2010; Beyer \& Hopner, 2003) because the legal protection of shareholders contributes negatively to the performance of the non-shareholders (Burkart \& $\mathrm{Pa}$ nunzi, 2006). However, some authors, such as Adams (2012), show that there are no significant differences between the governance in non-financial firms and financial firms (banks and nonbanks).

\section{Governance of financial entities during current crisis: short-term view, institutional investors and incentives}

In the present crisis, the corporate governance view has been of great importance, particularly within the banking sector (OECD, 2008). However, until the crisis erupted, research had not focused much on the governance of financial entities. For example, Adams (2012: 10) highlights this idea and establishes that "governance standards in the United States were quite high just prior to the financial crisis", whereas corporate governance, in general, had been intensely studied.

Although the literature focused on corporate governance (La Porta et al., 2000; Shleifer \& Vishny, 1997) not only because of the effect of the financial crisis, most academic papers excluded the banking sector from their data and focused on the governance of non- financial firms (Adams, 2012). This was likely due to the special nature of financial services. The management of financial entities has a series of specificities that affect their governance, thus requiring the adaptation of general rules of corporate governance to respond to their different natures (OECD, 2009; European Commission, 2010).

1 Opposing interests exist regarding risk preferences between the different stakeholders that participate in the financial entities. Shareholders are more interested in the entity taking on more risk than other stakeholders, such as depositors and other creditors. However, based on a narrow interpretation of contract theory, managers are obliged to satisfy shareholders' interests, which could suggest that it would be legitimate not to respond to other stakeholders' interests (Beyer \& Hopner, 2003).

2 Management's actions can have important consequences for collectives, such as depositors and contributors in general, and in the event of the failure of a financial entity, the effects can have a knockon, or ripple, effect on the whole economy.

3 Some risks, such as those affecting liquidity and reputation, occur more intensely in the financial sector than in other sectors.

4 Governments offer implicit or explicit guarantees and are expected to intervene in the entities' favor in the event of problems, and this has an influence on the incentives the different participants in the banking business receive.

All of these differences increase the importance of banking governance because of the impact on the stakeholders because of the assumed risks that affect others apart from the decision makers and because of the influence of asymmetries in power and information. Accordingly, it is necessary to establish some points about the end established in the financial company and to determine those differences that affect external and internal issues when modifying government decisions regarding financial institutions.

\section{Short-Term Vision of Shareholder-Oriented Banking Governance}

The shareholders who are the "owners" of the company, under the property right theory, would provide justification for corporate governance of the 
entities focusing on the satisfaction of their interests (Sternberg, 1998). Another justification is that the owners delegate management of the company to managers through contracts that are incomplete because they cannot regulate all of the factors that affect the relationship, thereby leaving the shareholders at a disadvantage.

Thus, corporate governance oriented toward protecting the rights of shareholders is reflected in the Principles of Corporate Governance published by the OECD in 2004 (OECD, 2004). It consists of six principles intended to provide the basis for companies to develop good practices of corporate governance. Within the six principles, there is an emphasis on the protection of shareholders, situating them as a collective whose rights must be defended as a priority. Shareholders are at the center of the ownership structure of the companies because of their right to make decisions based on their vote. Moreover, as their pay fluctuates in accordance with returns on equity, they ask for increased profits from the companies. Unfortunately, there is only a minimal attention given to the existence of other stakeholders, such as employees, creditors and suppliers, in terms provided them with access to relevant information and to defending the rights afforded them by law.

This approach to corporate governance favors institutional investors. They invest a good part of the capital they manage in shares and do so following the criteria to obtain increased profits. Therefore, if companies want to count on the support of the shareholders in their shareholder base, they must direct their governance towards the objectives that the institutional investors wish to achieve. When selecting the securities that make up their portfolios, the investors bear in mind those companies that have adopted a corporate governance structure (McCahery, Starks, \& Sautner, 2010), as such a structure favors the investors. Therefore, they will channel their investments towards companies whose main objective is the defense of the shareholders' interests.

The corporate governance of banks, while following a shareholder orientation, did so with a shortterm vision (Guttmann, 2009). Institutional investors employ a financial logic based on short-term share performance of a quarterly or semi-annual basis (European Commission, 2010; Larosière, 2009). This is why the management of companies in which institutional investors participate prioritizes immediate results rather than long-term outcomes, thus setting as their main management objective improvements in short-term share prices (Guttmann, 2009).

\section{The Influence of Institutional Investors in Corporate Bank Governance}

Along with the financial globalization and financialization of the economy, there has been an unprecedented growth of institutional investors that affect corporate bank governance (McCahery et al., 2010). Investment funds, pension funds and insurance companies have significantly expanded since the early 1980 s, and during the last decade of the $20^{\text {th }}$ century, the volume of their assets doubled. For example, Spain, between 2004 and 2005 realized an increase of $15.6 \%$ (Rabadan, 2006), which was stimulated by the processes of liberalization and deregulation. Institutional investors have a significant presence in the shareholder-base management corporations, thus giving shareholders the power to influence the governance (Becht et al., 2002). Considering the ample liquidity of today's financial markets, which is also a product of the liberalization and deregulation processes, shareholders are able to change positions quickly if the companies they invest in do not meet the criteria of profitability. In essence, they manage as they deem suitable based on the profit (Alvarez Peralta \& Medialdea, 2010).

Numerous studies find that corporate bank governance played a relevant role in the gestation of today's crisis (Klicksberg, 2010; OECD, 2008; 2009), but insufficient research has investigated the reasons that enabled corporate governance to evolve in a direction that made that influence possible. In general, it is possible to conclude that the influence of corporate governance on the crisis was produced through four channels (OECD, 2008; 2009).

1 Risk management systems: the system is not capable of preventing excessive risk taking (Laeven \& Levine, 2009).

2 The management bodies: the structure and performance of these bodies are in need of improvement.

3 The speculative nature of the investments made by shareholders: as Khurana \& Zelleke (2009) made clear, "few investors in these companies 
have cared much about the underlying company or the business it conducts. They do not stick around long enough for that". As a result, the defense of shareholder interests is left in the hands of company managers. The OECD declares that this passive role from institutional investors is common (OECD, 2009).

4 Manager incentives and remunerations: it is necessary to align actions of the managers of financial entities with shareholder interests, with the principal aim being to maximize shareholder value.

The first two channels are attributable to the internal functioning of these institutions. The other two are associated with institutional investors and are about the need to adapt governance of the entities to an environment that has greatly changed in the three decades prior to the crisis.

\section{Incentives for Financial Entity Managers}

Because the main objective of financial governance in the financial sector could be aligned with the maximization of short-term shareholder value (OECD, 2009), and considering the objective of institutional investors, the way in which the alignment of managerial actions was approached evolved in parallel with the main objective.

Following the postulates of agency theory, the administrators to whom owners delegate management are considered to have different interests and perspectives on risk than those of the owners (shareholders). The former are less willing to assume risk because all of their human capital is invested in the company, unlike the shareholders, whose investment portfolios have been diversified (Denis, 2001).

There are many ways to align managers' actions with shareholders' interests. However, with respect to corporate governance there are at least two - internal controls and manager incentives (Lang \& Jagtiani, 2010). Stock options were the most common incentives in the banking sector (Bebchuk \& Spamann, 2010). This form of remuneration is intended to commit managers to increase the share market value because doing so will increase their remuneration. In other words, their incentives influence their interest to increase the company's value in the market, which coincides with the goals of the shareholders.

\section{The results through corporate governance: moral hazard and the banking model}

In the present crisis, it is possible to suggest that by viewing posing governance of the entities from a short-term "shareholder" perspective (OECD, 2009) and incentivizing managers to use instruments that also catered to this short-term view, risk taking was excessively encouraged. Furthermore, the assumed model by banks, originate-to-distribute, was not beneficial in a more common management banking model with few negative collaterals. In this context, the originateto-distribute model encouraged excessive risk-taking due to the high level of moral hazard involved, given that the risk the entities were assuming with the loans granted was not borne by the borrowing entity, but by investors who underwrote the financial assets through those that were securitized.

\section{Assumed Risk in Banking: Moral Hazard}

The fact that managers and shareholders also suffered major losses in the crisis does not detract from the argument because, a priori, the decision to take on risk was perfectly rational given that the expectation behind the investment was to obtain profit. This may end up harming other collectives that participate in the company as holders of bonds and preferred participants, or the State, who do not receive the possible benefits of these risky transactions, but are affected by any losses that might be produced (Bebchuk \& Spamann, 2010; Corsetti, Pesenti \& Roubini, 1999; Krugman, 1999).

In their determination to get managers to favor shareholder interests, the entities did not pay proper attention to internal controls and went for the option of incentivizing managers with, principally, stock options, as we previously mentioned, thus encouraging the outbreak of the crisis (Lang \& Jagtiani, 2010).

Gibbons and Murphy, in 1990, identified certain dangers in this form of compensation, noting that it had negative consequences for the sector and for the market, though it did seem to have positive outcomes for the company. There were also studies that found that the risk the entities adopted increased with the degree to which there was growth in the weight of the stock options as remuneration for managers (Chen, Steiner \& Whyte, 2006) or that the effect of such re- 
munerations is an increase in the risk associated with the investments the entity makes (Mehran \& Rosenberg, 2008). This was, however, the model for incentivizing managers that was usually applied (Bebchuk \& Spamann, 2010).

The problems presented by this system arose from different sources.

1 It was not employed properly because most of the options were issued on price (Bebchuk \& Spamann, 2010), and it was applied without relativizing the increase in share price with the greater risks that were shouldered to obtain them (European Commission, 2010). The result was to encourage excessive risk taking by financial entities, which stimulated the crisis.

2 It did not ensure that the retributive levels of entity managers effectively matched their performance (OECD, 2008), and as a consequence, they were markedly asymmetrical. When the entity increased its profit, higher remuneration was received by the managers, but when the entity registered losses, this was not reflected by a decrease in salaries. Moreover, immediate results were rewarded, neglecting any evaluation of the risks incurred to achieve them (Bratton \& Watcher, 2010), which led to greater risk taking by the entities and undue remunerations for the managers (European Commission, 2010).

3 The system was not properly supervised by the shareholders' general meeting as it was not capable of ensuring that the defense of company interests was guaranteed over the long term (European Commission, 2010).

4 The managers benefitted from an even greater moral hazard than that of the shareholders because they profited from all the rises in stock prices but were not affected at all when the price dropped, as they held options rather than shares (Bebchuk \& Spamann, 2010). In addition, when problems begin to appear and the entities' share prices drop, the moral hazard grows because, when faced with lower share values, which places managers' stock options outside the market, shareholders and managers have less to lose, which also means they have more incentive to take risks (Bebchuk \& Spamann, 2010). In consequence, it seems reasonable to assume that after a crisis in which managers and shareholders have incurred great losses, the moral hazard problem can only increase.

Thus far, the analysis suggests that the banking management model and the governance of financial entities evolved hand-in-hand with the economic environment in which they acted, influenced by the need to adapt to it.

\section{Banking Transformation: Originate-to- Distribute Model}

This economic environment, which evolved due to the advance of globalization, facilitated the arrival of a new form of managing the banking business called the originate-to-distribute model". An effective and fast way to achieve profitability (Quigley, 2008), it principally developed between investment banks in certain countries including the United States and the United Kingdom.

The originate-to-distribute model works within completely different parameters (Brunnermeier et al., 2009; Mishkin, 2009) as the entity that grants the loans is no more than an intermediary between loan seekers and investors. The latter take on the credit risk in exchange for profitability. Risk transfer occurs via securitization, through which the entity that agreed to the loan transfers the risk of non-payment to the underwriter of the security. The entity can thereby grant more loans without needing greater regulatory capital. This system provided family economies and companies with access to cheaper financing and also opened up new types of securities to investors so they could diversify their portfolios, depending on the risk they wished to incur (Bernanke, 2008; Field \& Pérez, 2009).

Until the outbreak of the crisis, it was considered the banking model of the future, which would, in time, replace the traditional banking management model (Roldán, 2008). Today, however, it is considered a factor that led to the current crisis (Brunnermeier et al., 2009; Catarineu \& Pérez, 2008; Financial Crisis Inquiry Commission, 2011; Pérez, 2008; Roldán, 2008) where granting loans with lower credit quality status shares the risk rather than effectively managing the risk with experts and capable agents, and where securitization, with its complexity and lack of necessary transparency, is unable to determine and analyze the risk level of different entities and financial products. 


\section{Discussion and concluding remarks}

The banking sector played a major role in the gestation and outbreak of the crisis. The model that helps us to understand the present situation and explain the crisis should take into consideration problems of agency, moral hazard, over-indebtedness, and mistrust of investors and of the banks themselves in the solvency of the financial entities as they are all associated with the actions of financial entities and are attributable to the corporate governance as well as to their excessive interest in satisfying shareholder interests and obtaining short-term results.

The framework within which financial entities conducted their business changed very importantly during the three decades preceding the eruption of the crisis. This evolution in the financial environment was crucial in the changes that occurred in the management of these entities and the transformations that facilitated the banking actions that proved fundamental for the crisis. Financial globalization was one of these. Moreover, one of the consequences of financial globalization was the increase in the weight of the financial sector in the economy (financialization). As the sector grew, so did the reach of financial investors as they increasingly acquired more power, which they utilized to influence the corporate governance of the companies they participated in, thus fostering a shareholder vision of management. Additionally, during the gestation of the crisis, the propensity for risk presented by the shareholders of the financial entities was not sufficiently heeded. The shareholders may have wanted the entity to take risks because, if the businesses report profits, there would be no limit to their benefits because as company owners, they share in all the profits that are obtained, while their losses are limited to the amount of their contributions - the banking moral hazard. Therefore, the moral hazard could be considered an important contributing factor to the crisis because it impacts people who did not benefit from the profits and influences the losses without consciously assuming the risk of investments. As a result, those who did not benefit from the profits are the most negatively affected as they had not protection from the decisions of the financial institutions.

In this context, banking has adapted to the new neoliberal, deregulated, liberalized, globalized environment, giving rise to a new model of banking busi- ness called the "originate-to-distribute model", which is directly connected to the direction the present crisis has taken through the evolution of its corporate governance.

On the other hand, corporate bank governance has performed a key role in the gestation of this crisis through two main factors: the shareholder vision that was applied and that resulted in an unreasonably short-term approach to the banking business and the incentives that were supposed to result in managerial actions consistent with the institution's interests. The conflict of interest between shareholders, while interesting, suggests that it is necessary to establish stronger relationships between financial institutions and other shareholders. This study has also determined that the agency problem was a contributing factor to the financial crisis, and although it is assumed that shareholders' interests are based on obtaining profits, the shareholders could also be aware of the future bankruptcy of companies, which is an issue worthy of future analysis based on the statistical data. In summary, the main contribution of the present paper is that in addition to exploring the role played by corporate banking governance, it explains the factors responsible for such governance. From that point of departure, this study suggests that reforms must avoid a repetition of the events that caused the crisis and should examine the structural features of financial governance. Among these features, we advise considering the interests of other stakeholders in the financial entities, in addition to those of the shareholders. It is further recommended that, depending on the banking corporate governance, the features related to the regulations and limitations of the free market be investigated.

These conclusions must be weighed bearing in mind that one limitation of the study is that it is a theoretical analysis that has not been tested empirically using quantitative data. Furthermore, it concentrates on the specific case of the present economic crisis and is not, therefore, applicable for explaining previous crises, owing to the special circumstances of the current episode. In this regard, it would be interesting, on the one hand, to conduct an empirical contrast with statistical data, and on the other hand, to more deeply analyze risk management of financial entities, concentrating, in particular, on the moral hazard that has led to excessive risk taking. 


\section{References}

Adams, R. B. (2012). Governance and the Financial Crisis. International Review of Finance, 12 (1), 7-38.

Aizenman, J. (2002). Financial opening: evidence and policy options (Working Paper No. 8900). National Bureau of Economic Research.

Akerlof, G. A., \& Shiller, R. J. (2009). Animal Spirits: How Human Psychology Drives the Economy, and Why It Matters for Global Capitalism. Princeton, NJ: Princeton University Press.

Alvarez Peralta, N., \& Medialdea, G. B. (2010). La influencia de la financiarización sobre el gobierno corporativo de la empresa: el papel de los inversores institucionales [The Influence of Financialization on Corporate Governance of the Company: the Role of Institutional Investors]. Revista de Economía Mundial, 24, 165-191.

Alvarez Peralta, N., \& Medialdea, G. B. (2009). Financiarización, crisis económica y socialización de las pérdidas [Financialization, economic crisis and socialization of losses]. Viento Sur, 100, 21-32.

Arestis, P., Baltar, C. T, \& Cavalcante, A. (2009). La actual crisis financiera: el fin de la liberalización financiera? [The current financial crisis: the end of financial liberalization?]. Ekonomiaz, 72 (3), 12-33.

Bebchuk, L., \& Spamann, H. (2010). Regulating bankers’ pay. Georgetown Law Journal, 98 (2), 247-287.

Becht, M., Bolton, P., \& Röell, A. (2003). Corporate governance and control. In G. Constantinides, $\mathrm{M}$. Harris \& R. Stulz, (Eds.), Handbook of economics and finance (Vol. 1, pp. 1-109). Amsterdam: North Holland Publishing Co.

Bernanke, B. (2008, April 10). Addressing Weaknesses in the Global Financial Markets: The Report of the President's Working Group on Financial Markets (speech at the Affairs Council of Greater Richmond's Virginia Global Ambassador Award Luncheon. Richmond, Virginia: Board of Governors of the Federal Reserve System. Retrieved from www.federalreserve.gov, on 25 January 2013

Beyer, J., \& Höpner, M. (2003). The Disintegration of Organized Capitalism: German Corporate Governance in the 1990s. West European Politics, 26 (4), 179-198.

Blasiak, W. (2010). The Global Economic Crisis and the Global Accumulation of Capital. Contemporary Economics, 4 (2), 35-51.
Bordo, M., Eichengreen, B., Klingebiel, D., \& Martínez-Peira, M. S. (2001). Is the crisis problem growing more severe?. Economic Policy, A European Forum, 16 (32), 53-82.

Bratton, W. W., \& Wachter, M. L. (2010). The case Against Shareholder Empowerment. University of Pennsylvania Law Review, 158 (3), 653-728.

Brunnermeier, M., Crocket, A., Goodhart, C., Hellwig, M., Persaud, A., \& Shin, H. (2009, January 25). The Fundamental Principles of Financial Regulation. Paper presented at Geneva Report on the World Economy 11, Geneva, Geneva: International Center for Monetary and Banking Studies. Retrieved from http://www.princeton.edu/ hsshin/www/ Geneva.pdf

Burkart, M. \& Panunzi, F. (2006). Agency conflicts, ownership concentration, and legal shareholder protection. Journal of Financial Intermediation, 15 (1), 1-31.

Cabello, R. V., \& Magallon, U. I. (2009). Impacto de la crisis en el modelo de gestión de activos [Impact of the crisis on the asset management model]. Revista Mensual de Bolsas y Mercados Españoles, 179, 28-37.

Calvo, G., \& Mendoza, E. (2000). Rational Contagion and the Globalization of Securities Markets. Journal of International Economics, 51 (1), 79-113.

Catarineu, E., \& Pérez, D. (2008). La titulización de activos por parte de las entidades de crédito: el modelo español en el contexto internacional y su tratamiento desde el punto de vista de la regulación prudencial [Asset securitization by credit institutions: the Spanish model in the international context and its treatment from the point of view of prudential regulation]. Estabilidad Financiera, 14, 88-121.

Chen, C. R., Steiner, T. L., \& Whyte, A. M. (2006). Does stock option-based executive compensation induce risk-taking? An analysis of the banking industry. Journal of Banking and Finance, 30(3), 915-945.

Corsetti, G., Pesenti, P., \& Roubini, N. (1999). What caused the Asian currency and financial crisis?, Japan and the World Economy, 11 (3), 305-373.

De La Dehesa, G. (2009). La primera gran crisis financiera del siglo XXI [The first major financial crisis of the century]. Madrid: Alianza Publishing. 
De Santis, G., \& Imrohoroglu, S. (1997). Stock returns and volatility in emerging financial markets. Journal of International Money and Finance, 16 (4), 561-579.

Denis, D. K. (2001). Twenty-five years of corporate governance research... and counting. Review of Financial Economics, 10 (3), 191-212.

Díaz-Alejandro, C. (1985). Good-bye financial repression, hello financial crash. Journal of Development Economics, 19 (1), 1-24.

Edison, H., Levine, R., Ricci, L. A., \& Sløk, T. (2002). International Financial Integration and Economic Growth. Journal of International Money and Finance, 21 (6), 749-776.

Estevez, J. (2009). El hábitat de los especuladores [The habitat of speculators]. Papeles de relaciones eco sociales y cambio global, 105, 81-91.

European Commission. (2010, June 2). Corporate governance in financial institutions and remuneration policies: Green Paper, COM(2010) 284 final.

Falkowski, M. (2011). Financialization of commodities. Contemporary Economics, 5 (4), 4-17.

Fama, E. (1970). Efficient Capital Markets: A Review of Theory and Empirical Work. The Journal of Finance, 25 (2), 383-417.

Field, L., \& Pérez, D. (2009). El informe del grupo de alto nivel sobre supervisión financiera en la UE: el informe Larosière [The report of the High Level Group on Financial Supervision in the EU: Larosière report]. Estabilidad financiera, 16, 41-62.

Financial Crisis Inquiry Commission (2011) Final Report of the National Commission on the Causes of the Financial and Economic Crisis in the United States. Washington, DC: U.S. Government Printing Office. Retrieved from http://www.gpo.gov/ fdsys/pkg/GPO-FCIC/pdf/GPO-FCIC.pdf

Freeman, R.E. (1984). Strategic Management: A Stakeholder Approach. Boston, MA: Pitman.

Friedman, M. (1962). Capitalism and Freedom. Chicago, IL: University of Chicago Press.

Gibbons, R., \& Murphy, K. J. (1990). Relative performance evaluation for chief executive officers. Industrial and Labor Relations Review, 43 (3), 30-51.

Greenspan, A. (2010, March 9). The Crisis, Second Draft, Mimeo.

Guttmann, R. (2009). Introducción al capitalismo conducido por las finanzas [Introduction to financedriven capitalism]. Ola Financiera, 2, 20-56.
Harvey, D. (2005). A Brief History of Neoliberalism. Oxford, UK: Oxford University Press.

Jackowicz, K., Kowalewski, O., \& Kozłowski, L. (2011). The Short and Long Term Performance Persistence in the Central European Banking Industry. Contemporary Economics, 5 (4), 18-31.

Jakóbik, W. (2011). Theory of Economy as the Original Cause of the World Crisis. Contemporary Economics, 5 (2), 4-15.

Jensen, M. C., \& Meckling, W. H. (1976). Theory of the firm: managerial behavior, agency costs and ownership structure. Journal of Financial Economics, 3 (4), 305-360.

Kaminsky, G. L., \& Reinhart, C. M. (1999). The Twin Crises: the Causes of banking and Balance-ofPayments Problems. American Economic Review, 89 (3), 473-500.

Kaminsky, G. L., Linzondo, S., \& Reinhart, C. M. (1998). Leading indicators of currency crises (Staff Papers No. 45). International Monetary Fund.

Keller, W. (2002). International Technology Diffusion (Discussion Paper No. 3133). Centre for Economic Policy Research.

Khurana, R., \& Zelleke, A. (2009, February 8). You can cap the pay, but the greed will go on. The Washington Post. Retrieved from http://articles.washingtonpost.com/2009-02-08/opinions/36888542_1_ executives-john-thain-business-leaders

Klicksberg, B. (2010). Las fallas en el gobierno corporativo. Un tema clave en la crisis económica mundial [Failures in corporate governance. A key issue in the global economic crisis]. Revista del CLAD Reforma y Democracia, 47, 71-88.

Kowalewski, O. (2012). Corporate Governance and Pension Fund Performance. Contemporary Economics, 6 (1), 14-44.

Krugman, P. (1999). The role of geography in development. In B. Pleskovic \& J. E. Stiglitz, (Eds.), Annual World Bank Conference on Development Economics 1998. (pp. 89-108). Washington, DC: The World Bank.

La Porta, R., Lopez-de-Silanes, F., Shleifer, A., \& Vishny, R. (2000). Investor protection and corporate governance. Journal of Financial Economics, 58 (1-2), 3-27.

Laeven, L., \& Levine, R. (2009). Bank governance, regulation and risk taking. Journal of Financial Economics, 93 (2), 259-275. 
Lang, W., \& Jagtiani, J. A. (2010). The mortgage and financial crises: The role of credit risk management and corporate governance. Atlantic Economic Journal, 38 (2), 123-144.

Larosière, J. (2009). The High-Level Group on Financial Supervision in the EU. Report. Brussels: European Commission. Reterieved from http://ec.europa. eu/internal_market/finances/docs/de_larosiere_ report_en.pdf

Levine, R. (2001). International financial liberalization and economic growth. Review of International Economics, 9 (4), 688-702.

Lucas, R. E. (1972). Expectations and the Neutrality of Money. Journal of Economic Theory, 4 (2), 103-124.

Ludescher, J. C., Mashud, R., \& Prusia, G. E. (2012). We Are the Corporation: Dispersive CSR. Business and Society Review, 117 (1), 55-88.

McCahery, J. A., Starks, L. T., \& Sautner, Z. (2010). Behind the Scenes: The Corporate Governance Preferences of Institutional Investors (Research Paper No. 10). Tilburg University - School of Law.

McCahery, J. A., Starks, L. T., \& Sautner, Z. (2010). Behind the Scenes: The Corporate Governance Preferences of Institutional Investors (AFA 2011 Denver Meetings Paper; Tilburg Law School Research Paper No. 010/2010.) Retrieved from http:// ssrn.com/abstract=1571046 or http://dx.doi. org/10.2139/ssrn.1571046

Mehran, H., \& Rosenberg, J. (2008). The Effects of Employee Stock Options on Bank Investment Choice, Borrowing, and Capital (Staff Reports No. 305). Federal Reserve Bank of New York.

Mishkin, F. S. (1999). Global Financial Instability: Framework, Events, Issues. Journal of Economic Perspectives, 13 (4), 3-20.

Mishkin, F. S. (2009). Is Monetary Policy Effective During Financial Crises? (Working Paper No. 14.678). National Bureau of Economic Research.

Omran, M., Atrill, P., \& Pointon, J. (2003). Shareholders Versus Stakeholders: Corporate Mission Statements and Investor Returns. Business Ethics: A European Review, 11 (4), 318-326.

Organization for Economic Cooperation and Development (2004). OECD principles of corporate governance. Paris: OECD. Retrieved from http:// www.oecd.org/corporate/ca/corporategovernanceprinciples/31557724.pdf
Organization for Economic Cooperation and Development (2008). The corporate governance lessons from the financial crisis. Paris: OECD. Retrieved from http://www.oecd.org/finance/financial-markets/42229620.pdf

Organization for Economic Cooperation and Development. (2009). Corporate Governance and the Financial Crisis. Key findings and main messages. Paris: OECD. Retrieved from http://www.oecd.org/corporate/ca/ corporategovernanceprinciples/43056196.pdf

Purnanandan, A. (2010). Originate-to-Distribute Model and the Subprime Mortgage Crisis. Review of Financial Studies, 24 (9), 1.881-1.915.

Quigley, J. M. (2008, October 13 online). Compensation and incentives in the mortgage business, Economists' Voice, 5(6) Retrieved from http://www.degruyter.com/view/j/ev.2008.5.6/ev.2008.5.6.1431/ ev.2008.5.6.1431.xml?format=INT

Rabadan, M. (2006). Planes y fondos de pensiones: presente y futuro [Pension plans and funds: present and future]. Revista ICE, 833, 27-38.

Recalde, A. (2009). El papel del "Derecho" en la crisis. Algunos aspectos de la regulación financiera y de las grandes empresas en su relación con la Economía (Laboratorio de alternativas documento de trabajo No. 150/2009). Madrid: Fundación Alternativas.

Recio, A. (2009). La crisis del neoliberalismo [The crisis of neoliberalism]. Revista de Economía Crítica, 7, 96-117.

Richards, A. (1996). Volatility and Predictability in National Stock Markets: How Do Emerging and Mature Markets Differ? (Working Paper No. 96/29). International Monetary Fund.

Rodrik, D. (2001). Trading in Illusions. Foreign Policy, $123,55-62$.

Roldan, J. M. (2008). El papel del modelo de «originar para distribuir» en la crisis financiera de 2007 [The role model of "originate to distribute" in the financial crisis of 2007]. Estabilidad Financiera, $15,9-20$.

San-Jose, L., \& Retolaza, J. L. (2012). Participation of Stakeholders in Corporate Governance: Foundation Ontological and Methodological Proposal. Universitas Psychologica, 11 (2), 619-628.

San-Jose, L., Retolaza, J. L., Urionabarrenetxea, S., RuizRoqueñi, M., \& Azkunaga, A. (2013). The New Paradigm of Corporate Finance: Ethics in Finance, ICTs, Financial Globalization and Stakeholder Re- 
sponsibility. International Research Journal of Finance and Economics, 103 (1), 191-206.

Shleifer, A., \& Vishny, R. W. (1997). A Survey of Corporate Governance. Journal of Finance, 52 (2), 737-783.

Soto, R. (2010). Desregulación financiera y finanzas públicas en México [Financial Deregulation and Public Finance in Mexico]. Economía Informa, 362, 48-58.

Spong, K., \& Sullivan, R. J. (2012). Bank Ownership and Risk Taking: Improving Corporate Governance in Banking after the Crisis. In J. R. Barth, C. Lin, \& C. Wihlborg (Eds.), Research Handbook on International Banking and Governance (pp. 163179). Northampton, MA: Edward Elgar Publishing Limited.

Sternberg, E. (1998). Corporate Governance: Accountability in the Marketplace. London, UK: Institute of Economic Affairs.

Stiglitz, J. E. (2002). Globalization and Its Discontents. New York, NY: W. W. Norton \& Company.

Stiglitz, J. E. (2010). Freefall: Free Markets and the Sinking of the World Economy. New York, NY: W. W. Norton \& Company.

Summers, L. H. (1986). Does the Stock Market Rationally Reflect Fundamental Values?. Journal of Finance, 41 (3), 591-601.

The Committee on the Financial Aspects of Corporate Governance (1992). Report of the Committee on the Financial Aspects of Corporate Governance. London, UK: Gee \& Co Ltd.

Urionabarrenetxea, S., Bañales, A., \& García J. D. (2009). Análisis de los factores determinantes del crecimiento de la economía real en un contexto de globalización financiera [Analysis of the determinants of real economic growth in a context of financial globalization]. Revista de Economía Mundial, 22, 221-246.

Wilczyński, R. (2011). Global Financial Governance: a Perspective from the International Monetary Fund. Contemporary Economics, 5 (1), 4-16.

World Economic Outlook. (2006, September). How Do Financial Systems Affect Economic Cycles? Retrieved from http://www.imf.org/external/pubs/ $\mathrm{ft} /$ weo/2006/02/pdf/weo0906.pdf

Zamil, S. (2010). El día del juicio [The day of judgment]. Finanzas \& Desarrollo, 47 (3), 44-47.

\section{Acknowledgements}

We thank Chris Cowton, Antonio Argandoña, Jose Luis Retolaza and Miguel Alzola for their useful comments and remarks during preparations and discussions of the paper. We also thank the three referees for their anonymous work to improve the quality of this paper. Finally, we thank the research group ECRI Ethics in Finance and Governance (www.ehu.es/ecri), which was supported by the UPV/EHU and the Basque Government research projects EHUA 12/04 titled "Value-added model in financial relationships from stakeholders' orientation" from the 2012 call. 
